\title{
PAGET'S DISEASE OF THE VULVA TREATED BY WIDE EXCISION AND RECONSTRUCTION WITH SKIN GRAFTS AND FLAPS: REPORTS OF THREE CASES
}

\author{
Dong-Hyu Cho, MD', Si-Gyun Roh, MD², Jeong-Heon Lee, MD \\ Departments of ${ }^{1}$ Obstetrics and Gynecology, ${ }^{2}$ Plastic and Reconstructive Surgery, Chonbuk National University Medical School, Jeonju, Korea
}

Extramammary Paget's disease is a rare, slow-growing, non-invasive intraepithelial adenocarcinoma that occurs mainly in the elderly outside of the mammary gland. Paget's disease of the vulva accounts for less than $1 \%$ of all vulvar malignancies. The standard treatment is wide local excision of the gross lesion. To prevent a relapse, wide excision with adequate margins is necessary not to leave pathologic lesions around margins of excision. However, since the excised area is too wide to cover all the exposed surface with a simple closure only, skin grafts and flaps can be very useful. We report successful treatment of three cases of extramammary Paget's disease of the vulva using frozen section analyses of the margins during operation in order to attain Paget's cells free margins and skin grafts and flaps to cover an extensive defects.

Keywords: Paget's disease; Vulva; Skin grafts and flaps

파제트병(Paget's disease)은 심한 가려움증을 동반하고 경계가 명확 한 붉은색의 습진 같은 병변을 나타내는 드문 상피내악성종양으로 유 두나 유륜에 발생하는 유방 파제트병(mammary Paget's disease)과 회 음부, 겨드랑이, 앞가슴부위, 팔, 손가락 등에 발생하는 유방외 파제트병 (extramammary Paget's disease)으로 나뉜다. 외음부 파제트병은 전체 외음부 종양의 약 $1 \%$ 이하를 차지하며 주로 폐경여성에서 발생한다[1]. 조직학적 발생기전은 현재까지 명확히 알려지지 않았으며, 대부분 천천 히 진행하여 수년 동안 국소적으로 남아 있기도 하지만 조직을 침윤하 기도 하고, 일부에서는 소화기 또는 비뇨생식기계의 내부에 암이 동반 되는 경우도 있다[2]. 외음부 파제트병의 치료는 광범위 국소절제술을 시행하는 것이 가장 좋은 방법으로 재발을 방지하기 위해서는 충분한 절제연을 설정하여 광범위 절제술을 시행해야 한다. 이럴 경우 단순 봉 합만으로 결손 부위를 재건하는 것은 매우 어려우므로 피부이식과 피판 술을 이용한 재건술이 상당히 유용하다.

저자들은 피하조직을 포함한 광범위 국소절제술 후 피부이식과 피판 술을 이용한 회음부 재건술을 시행하여 성공적으로 치료하였던 외음부 파제트병 3예를 경험하였기에 문헌 고찰과 함께 보고하는 바이다.

\section{증례1}

환 자: 강 $\mathrm{O}$ 자, 61 세
산과력: 3-0-3-3

과거력: 2007년 11월 당뇨병 진단 후 현재까지 약물복용 중이었다.

가족력: 특이사항 없었다.

월경력: 초경은 15 세에 있었고 월경 주기는 30일로 규칙적이었으며, 7 일 정도 지속되었고 54 세에 폐경되었다.

현병력: 약 2년 전부터 외음부에 갈색 병변이 생기고 가려움증이 있어 개인병원에서 간헐적으로 증상 완화를 위한 치료를 하였으나 호전되지 않아 본원 피부과에서 조직검사 결과 유방외 파제트병으로 진단되어 산 부인과로 전과되었다.

Received: 2011. 4. 4. Revised: 2011. 5.17. Accepted: 2011. 6.16. Corresponding author: Jeong-Heon Lee, MD

Department of Obstetrics and Gynecology, Chonbuk National University Medical School, 634-18 Geumam-dong, Deokjin-gu, Jeonju 561-712, Korea

Tel: +82-63-250-1360 Fax: +82-63-254-4833

E-mail: jh.lee@jbnu.ac.kr

This is an Open Access article distributed under the terms of the Creative Commons Attribution Non-Commercial License (http://creativecommons.org/licenses/ by-nc/3.0/) which permits unrestricted non-commercial use, distribution, and reproduction in any medium, provided the original work is properly cited.

Copyright $\odot$ 2011. Korean Society of Obstetrics and Gynecology 


\section{KOREAN JOURNAL OF OBSTETRICS \& GYNECOLOGY}

Dong-Hyu Cho, et al. Vulvar Paget's disease treated by excision and reconstruction
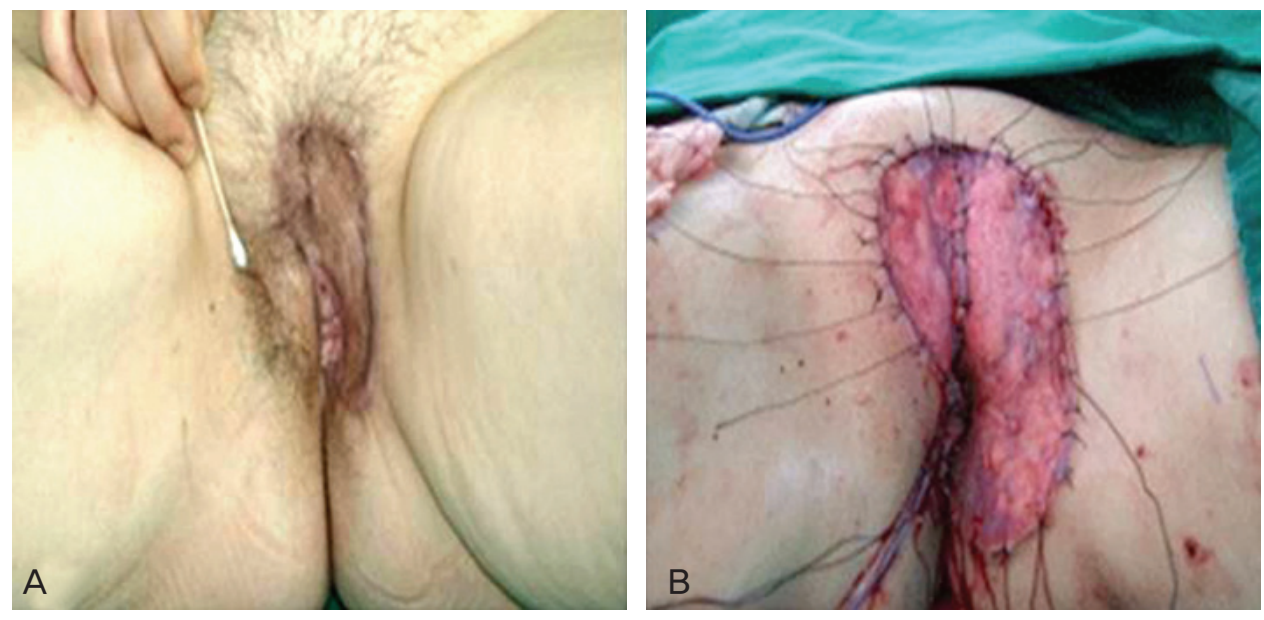

Fig. 1. Preoperative finding: eczematoid lesion on left labium major (A). Postoperative finding: wide local excision and coverage by split-thickness skin graft (B).
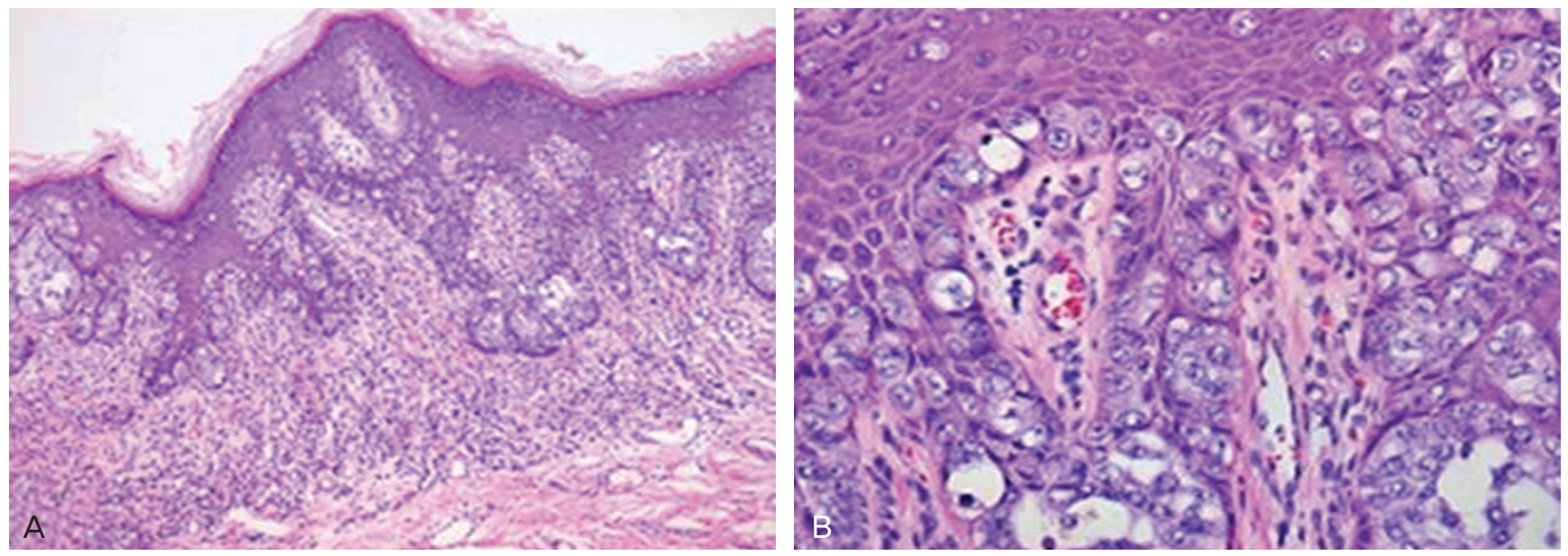

Fig. 2. Microscopic features of vulvar Paget's disease. Large pale tumor cells dispersed singly or in clusters of solid nests and glandular spaces within the epidermis $(H \& E, \times 100)(A)$. Tumor cells have abundant pale cytoplasm with large nucleus and prominent nucleolus at high-power view (H\&E, $\times 400)(B)$.

진찰 소견: 왼쪽 대음순 부위에 약 $6 \times 4 \mathrm{~cm}$ 크기의 비교적 경계가 명확 한 갈색의 피부 병변이 있었으며, 통증이나 진물은 없었다(Fig. 1A). 오 른쪽 대음순은 이상 소견이 없었으며, 골반 진찰에서 질과 자궁은 위축 되어 있었고 자궁부속기는 특별한 이상이 없었다.

검사 소견: 전혈검사에서 혈색소 $13.6 \mathrm{~g} / \mathrm{dL}$, 혈침 $39.4 \%$, 백혈구 $5,280 / \mathrm{mm}^{3}$ 이었으며, 간기능검사는 aspartate aminotransferase $58 \mathrm{U} /$ $\mathrm{L}$, alanine aminotransferase $99 \mathrm{U} / \mathrm{L}$ 로 약간 상승되었고, 신기능 및 흉부 X선검사, 심전도검사에서 이상은 없었다. 자궁경부 세포도말검사, 골반 컴퓨터단층촬영, 유방촬영술, 유방 초음파 및 위, 대장 내시경 검사 소견 은 모두 정상이었다.

수술 소견: 전신마취하에 병변에 대한 광범위 절제술 및 외음부 전절제 술 시행 후 외음부 주위로 $15 \times 6 \mathrm{~cm}, 8 \times 4 \mathrm{~cm}$ 크기의 피부 및 피하조직 결손에 대하여 우측 대퇴부를 공여부로 하는 부분층 피부이식술(두께 0.010 inch)을 시행하였다(Fig. 1B).

병리학적 소견: 현미경 관찰에서 표피내에 투명하고 풍부한 세포질과 뚜렷한 호산성의 핵소체를 가진 파제트 세포가 보였고(Fig. 2), 면역조직
화학적 염색에서 epithelial membrane antigen (EMA) 및 cytokeratin 7 (CK 7) 양성이었고, S-100 단백질 및 human melanoma black 45 $(\mathrm{HMB}-45)$ 검사에서는 음성이었다.

수술 후 경과:" 수술 상처는 합병증 없이 회복되어 수술 후 29일째 퇴원 하였다. 퇴원 후 특별한 이상 없이 지내셨고, 현재까지 12 개월간 추적 관찰 동안 재발은 없었다.

\section{증례2}

환 자: 김 $\mathrm{O}$ 순, 70 세

산과력: 4-0-0-4

과거력: 30년 전 자궁근종으로 전자궁절제술 시행 받았다.

가족력: 특이사항 없었다.

월경력: 초경은 16세에 있었고 월경 주기는 30일로 규칙적이었으며, 지 속기간은 5일이었고 50세에 폐경되었다. 


\title{
KOREAN JOURNAL OF OBSTETRICS \& GYNECOLOGY
}

\author{
KJOG Vol. 54, No. 8, 2011
}
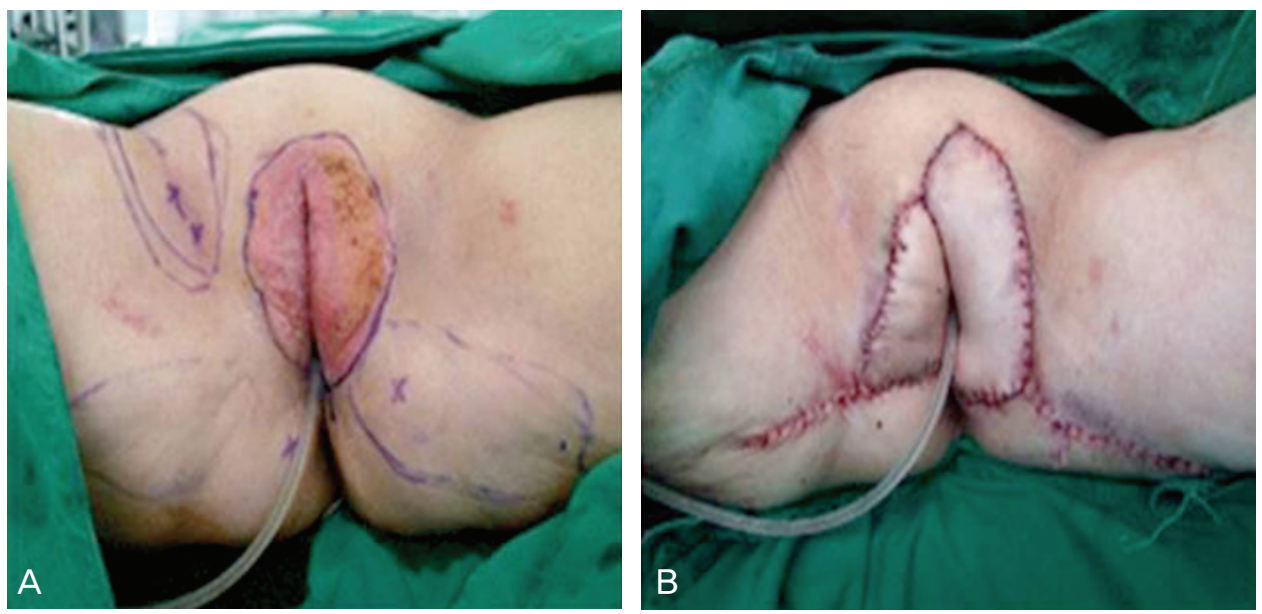

Fig. 3. Preoperative finding: reddish eczematoid lesion on both labium major (A). Postoperative finding: wide local excision and coverage by bilateral perineal perforator island flap (B).
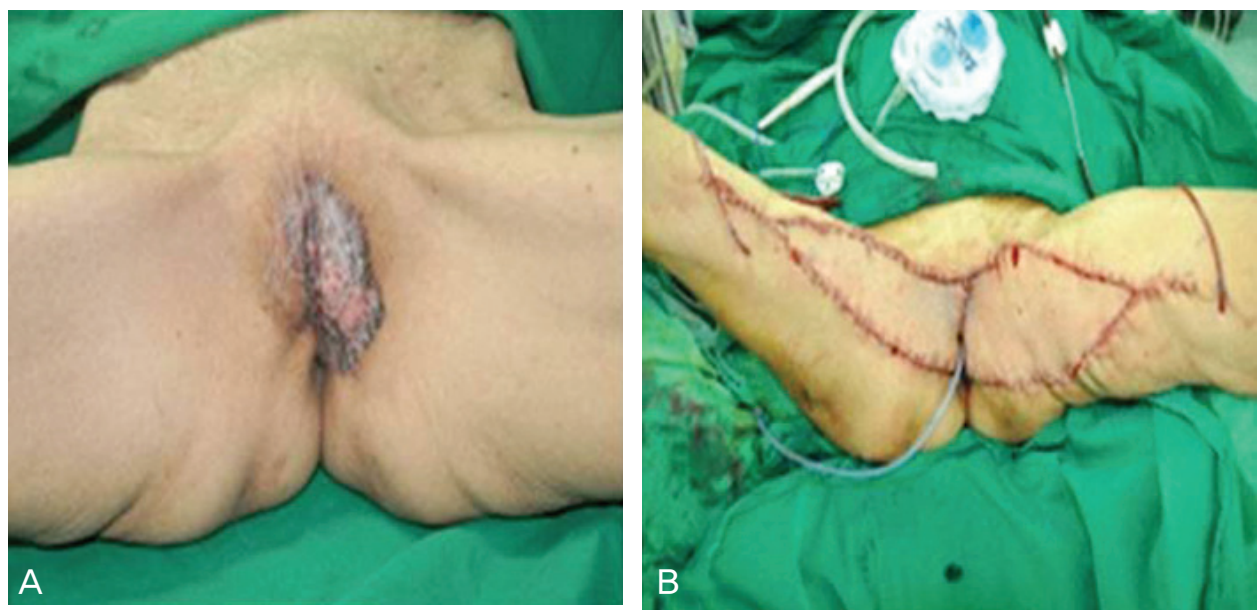

Fig. 4. Preoperative finding: eczematoid lesion on both labium major (A) Postoperative finding: wide local excision and coverage by bilateral media thigh perforator based $V-Y$ advancement flap (B).

현병력: 약 3년 전부터 질입구에 가려움증이 있는 붉은색 판모양의 병변 때문에 개인병원에서 간헐적으로 증상 완화 치료를 하였으나 점차 병변 이 커지면서 통증이 생겼고, 심한 부종이 지속되어 본원 피부과에서 조 직검사 결과 유방외 파제트병으로 진단받고 산부인과로 전과되었다.

진찰 소견: 양측 대음순의 내외측 면에 왼쪽은 약 $7 \times 4 \mathrm{~cm}$, 오른쪽은 약 $6 \times 3 \mathrm{~cm}$ 크기의 비교적 경계가 명확한 붉은 판모양 습진성 피부 병변이 있었으며, 인설이 있고, 통증이 심했고 진물이 흐르고 있었다(Fig. 3A). 골반진찰 소견에서 질과 자궁은 위축되어 있었으며, 자궁부속기는 특별 한 이상이 없었다.

검사 소견: 전혈검사는 혈색소 $13.8 \mathrm{~g} / \mathrm{dL}$, 혈침 $42.0 \%$, 백혈구 6,120 / $\mathrm{mm}^{3}$ 이었으며, 간기능검사, 신기능 및 흉부X선검사, 심전도에서 이상이 없었다. 자궁경부세포도말검사, 골반 컴퓨터단층촬영, 유방촬영술, 유방 초음파 및 위, 대장 내시경 검사 모두 정상이었다.

수술 소견: 전신마취하에 병변을 광범위 절제하였고 이로 인해 생긴 $10 \times 15 \mathrm{~cm}$ 크기의 피부 및 피하조직 결손은 양측성 항문주위 천공지도 서형피판술(bilateral perianal perforator island flap)을 이용하여 복원하 였다(Fig. 3B).

병리학적 소견: 현미경 관찰에서 파제트 세포들이 표피내에 한 개씩 흩
어져 있거나 혹은 여러 개가 모여 군집을 이루는 것이 보였으며 절제연 에서 파제트 세포는 보이지 않았다. 면역조직화학적 염색에서 EMA 및 CK 7 양성이었고, S-100 단백질 및 HMB-45 검사에서는 음성이었다. 수술 후 경과: 폐색전증 및 수술상처 치유지연 등의 합병증이 발생하였 으나 완쾌되어 수술 후 40 일째 퇴원하였다. 퇴원 후 특별한 이상 없이 지내시며 현재까지 14 개월 추적 관찰 동안 재발은 없었다.

\section{증례3}

\section{환 자: 김 $O$ 순, 72 세}

산과력: 3-0-0-3

과거력 및 가족력: 특이사항 없었다.

월경력: 초경은 12세에 있었고 월경 주기는 30일로 규칙적이었으며, 5 일 정도 지속되었고 54 세에 폐경되었다.

현병력: 약 2년 전부터 시작된 가려움증이 있는 회백색의 외음부 병변 때문에 본원을 방문하여 피부과에서 시행한 조직검사 결과 유방외 파제 트병으로 진단받고 산부인과로 전과되었다. 


\section{KOREAN JOURNAL OF OBSTETRICS \& GYNECOLOGY}

Dong-Hyu Cho, et al. Vulvar Paget's disease treated by excision and reconstruction

진찰 소견: 양측 대음순의 내외측 면에 왼쪽은 약 $7 \times 4 \mathrm{~cm}$, 오른쪽은 약 $4 \times 3 \mathrm{~cm}$ 크기의 비교적 경계가 명확한 회백색의 피부 병변이 있었으며, 인설, 가피 그리고 약간의 궤양이 있었으나 통증과 진물은 없었다(Fig. $4 \mathrm{~A})$. 골반진찰 소견에서 질과 자궁은 위축되어 있었으며, 자궁부속기는 특별한 이상이 없었다.

검사 소견: 전혈 검사에서 혈색소 $11.9 \mathrm{~g} / \mathrm{dL}$, 혈침 $36.4 \%$, 백혈구 $4,750 / \mathrm{mm}^{3}$ 이었으며, 간기능검사, 신기능 및 흉부X선검사, 심전도검사 에서 이상이 없었다. 자궁경부세포도말검사, 골반 컴퓨터 단층촬영, 유 방촬영술, 유방초음파 및 위, 대장 내시경 검사는 정상이었다.

수술 소견: 전신마취하에 외음부에 발생한 유방외 파제트병에 대한 광 범위 병변절제술 및 외음부 전절제술 시행 후 발생한 $15 \times 13 \mathrm{~cm}$ 의 피 부 및 피하조직 외음부 결손 부위는 양측 대퇴부 내측 $\mathrm{V}-\mathrm{Y}$ 전진피판술 을 이용하여 재건하였다(Fig. $4 \mathrm{~B})$.

병리학적 소견: 현미경 관찰에서 표피내에 풍부하고 맑은 세포질, 커다 란 핵, 뚜렷한 호산성의 핵소체를 가진 파제트 세포가 관찰되었고, 절제 연에 남겨진 파제트 세포는 없었다.

수술 후 경과: 수술 상처는 합병증 없이 회복되어 수술 후 29일째 퇴원 하였다. 퇴원 후 특별한 이상은 없었으며, 현재까지 12 개월간 재발 없이 외래에서 추적 관찰 중이다.

\section{고 찰}

유방외 외음부 파제트병은 병리학적으로 유방 파제트병과 유사한 소 견을 보이는 드문 상피내선암종으로 대부분은 외음부의 모낭이 있는 부 위에서 흔히 발생하며, 가장 흔한 증상은 가려움증을 동반한 습진 같은 병변으로 경계가 명확한 붉은색의 반으로 나타나고 병변 내에 궤양, 인 설, 각질화 등이 나타날 수 있으며, 그 외에 타는 듯한 느낌, 통증, 출혈 등을 호소하기도 한다[2]. 하지만 대부분이 다른 만성 피부 질환으로 오 인되어 진단이 늦어지는 경우가 많다. 본 증례의 세 명의 환자의 경우에 도 만성 습진성 피부질환으로 오인되어 처음 증상이 생긴 후 2-3년이 경과된 시점에서 외음부 파제트병으로 진단되었다.

외음부 파제트병의 발병기전은 아직 정확히 밝혀지지 않았으나, 최근 에는 발생기원에 따라 표피나 아포크린 한선 같은 피부에서 기원하는 원발성 유방외 파제트병과 직장, 자궁경부, 방광 등에 발생한 선암종과 같은 내부 장기암의 표피내 침습이나 전이로 발생하는 속발성 유방외 파제트병으로 분류하고 있다[3].

유방 파제트병은 대부분 피하에 암종을 동반하는 반면, 외음부 파제 트병은 약 10-12\%에서 침윤성이며, 4-8\%에서 국소선암종을 동반한 다. 항문 점막을 침범했을 경우 직장선암종을 동반하기도 하며 그 외 자 궁경부암, 기저세포암, 유방암, 신요로계암 등이 발생될 수 있으므로 자궁 경부 세포진검사, 유방촬영술, 방광경검사, 대장경검사, 복부골반단층촬 영 등의 검사도 시행해야 한대[4-6]. 본 연구의 세 증례들의 경우에도 앞 서 제시한 검사를 통해 타 부위의 병발 병소가 없다는 것을 확인하였다.

조직학적으로 파제트 세포는 표피세포 내에 크고 강하게 염색되는
다형성의 핵과 풍부한 세포질을 특징으로 하며, 세포의 $90 \%$ 이상은 mucin을 포함하고 있어 periodic acid schiff (PAS)와 alcian blue에 강하 게 염색되고 diastase-PAS에는 염색되지 않는 특징을 가지고 있다. 본 세 증례들에서도 생검을 통해 얻은 조직에서 시행한 PAS와 alcian blue 염색에서 모두 양성 반응을 보였다.

진단의 정확도를 높이기 위해 면역조직화학 반응 검사를 시행할 수 있는데 파제트 세포는 lectins peanut agglutinin, dolichos biflorus agglutinin, wheat germ agglutinin 등에 양성 반응을 보이며, 아포크린 조직에 특징적인 acid phosphatase, esterases 및 에크린 조직에 특 징적인 amylophosphorylase, leucineaminopeptidase에도 양성 반응 을 보인다. 또한 상피세포 관련 항원인 CK 7, 땀샘 관련 항원인 EMA, carcinoembryonic antigen, gross cystic disease fluid protein-15, 뮤신 관련 항원인 mucin glycoprotein1, MUC5AC 및 안드로겐 수용체에도 양성 반응을 보인다. 악성 흑색종과 감별하기 위해 S-100 단백질 및 $\mathrm{HMB}-45$ 검사를 시행하여 이 검사가 음성일 경우 파제트병이라고 진 단할 수 있다[7,8]. 본 세 증례들에서도 EMA 및 CK 7 양성 결과를 보 였으며, S-100 단백질 및 HMB-45 검사에서 음성 결과를 보였다.

파제트병의 일차 치료는 외과적 절제술로 조직학적 침범정도에 따라 차이가 있다. 상피내 파제트병이나 미세 침윤성 파제트병은 육안적으로 보이는 모든 병변부위와 정상 피부가 1-2 cm 포함되도록 충분히 확장 된 경계부위를 확보하여 국소절제술을 시행하고, 침윤성인 경우 외음부 편평세포암과 같은 방법으로 광범위 외음부 절제술 및 림프절 절제술을 시행해야 한다[1,2,4]. 그러나 파제트병은 육안적으로 보이는 임상적인 병변보다 파제트 세포의 침윤이 광범위한 경향이 있고 다발성의 가능 성 때문에 약 $30 \%$ 의 높은 재발률을 보여주고 있다. 이러한 높은 재발률 을 낮추기 위해 수술 중 동결절편검사를 실시하여 절제연에 파제트 세 포 음성을 확인하는 방법을 적용하기도 하지만, 이의 효용성 여부는 연 구자마다 차이가 있으며 절제연 상태와 병의 재발률과는 관계가 없다 는 보고도 있다[9-12]. 본 세 가지 증례들의 경우 수술중 동결절편 검사 를 실시하여 절제연 음성을 확인하면서 병변에서 $1 \mathrm{~cm}$ 이상의 간격을 두고 피하조직을 포함한 광범위 국소절제술을 시행하였으며, 수술 후 발생한 피부 및 연부조직 결손에 대해서는 피부이식 및 다양한 피판술 을 이용하여 회음부 결손 부위를 재건하였다. 이전의 수술 방법은 대부 분 광범위 절제 후 피부절제연을 끌어다 단순 봉합을 시도하였기 때문 에, 광범위한 피부 병변에 대해서는 충분한 외과적 절제가 시행되지 못 하여 깨꼿한 절제연을 얻기에 어려움이 있었다. 저자들은 이러한 문제 점들을 개선하기 위해 충분한 광범위 국소절제술 후 발생한 넓은 결손 부위에 대해 피부이식 및 피판술을 이용함으로써 효과적인 병변의 절제 및 재건이 가능하였다. 또한, 수술 후 12 개월 이상 추적관찰을 시행하였 는데 아직까지 재발소견은 보이지 않았다. 광범위 국소절제술 후 피부 이식 및 피판술이 파제트병의 재발을 줄일 수 있는지에 대한 객관적인 자료들은 없으나, 최근 Roh 등[13]이 발표한 연구에 의하면 병변 이외 의 정상 조직 제거 비율이 높을수록 재발률이 더욱 낮음을 보여주고 있 어 정상 조직을 가능한 많이 포함한 광범위 절제술 후 넓은 피부 결손에 대한 피부이식 및 피판술이 유용할 수 있음을 짐작할 수 있다. 하지만, 


\title{
KOREAN JOURNAL OF OBSTETRICS \& GYNECOLOGY
}

\author{
KJOG Vol. 54, No. 8, 2011
}

충분한 국소절제술을 시행한 후 피부이식 및 피판술을 이용한 경우에도 조직발생학적으로 명확하게 설명할 수 없는 이식 및 피판 부위 파제트 병 재발이 있었으며, 치료한 지 15년 이후에도 재발한 경우도 있어 반드 시 장기적으로 세심한 추적관찰을 해야 하겠다[14,15].

수술적 치료로 완전한 제거가 불가능한 경우, 전신상태가 불량한 경우 또는 재발한 경우에는 항암화학치료나 방사선 치료 등을 시행해 볼 수 있으며, 5-FU 연고 또는 5\% imiquimod 연고 도포 등을 이용한 방법들이 효과가 있었다는 보고가 있으나 아직까지 이러한 비침습적인 치료 방법 들에 대한 명백한 효과에 대해서는 아직 확립되어 있지 않다.

일반적으로 예후와 관련된 인자는 침범 깊이, 절제연 상태, 내부 장기 암의 동반 여부, 림프절 침범 여부 등이며, 상피 내에 국한되어 있는 경 우가 $1 \mathrm{~mm}$ 이상의 진피 침범이 있거나 내부 장기암이 동반되는 경우보 다 예후가 좋다.

결론적으로, 외음부에 만성적인 피부 질환을 가진 환자일 경우 비특 이적 증상으로 인하여 다른 피부 질환과의 감별이 어려워 진단이 늦어 질 수 있으므로 의심되는 경우 조직검사를 통해 확진해야 한다. 파제트 병으로 확진되었을 경우 충분한 검사를 통해 내부 장기암의 동반 여부 를 배제한 후 외과적 절제술을 시행해야 하며, 수술 시 동결절편검사를 실시하여 절제연 음성을 확인하면서 충분한 광범위 국소절제술을 시행 하고, 이 때 발생한 피부 및 피하조직의 넓은 결손에 대해서는 피부이식 및 다양한 피판술을 이용할 경우 좀 더 효과적으로 치료할 수 있을 것으 로 생각된다.

\section{References}

1. Black D, Tornos C, Soslow RA, Awtrey CS, Barakat RR, Chi DS. The outcomes of patients with positive margins after excision for intraepithelial Paget's disease of the vulva. Gynecol Oncol 2007; 104:547-50.

2. Tebes $S$, Cardosi R, Hoffman M. Paget's disease of the vulva. Am J Obstet Gynecol 2002;187:281-3.

3. Wilkinson EJ, Brown HM. Vulvar Paget disease of urothelial origin: a report of three cases and a proposed classification of vulvar Paget disease. Hum Pathol 2002;33:549-54.

4. Fanning J, Lambert HC, Hale TM, Morris PC, Schuerch C. Paget's disease of the vulva: prevalence of associated vulvar adenocarcinoma, invasive Paget's disease, and recurrence after surgical excision. Am J Obstet Gynecol 1999;180:24-7.

5. Yoon MK, Jeon YE, Park YH, Kim SJ, Kang JB, Jang BR, et al. A case of vulvar adenocarcinoma associated with extramammary Paget's disease. Korean J Obstet Gynecol 2006;49:93944.

6. Feuer GA, Shevchuk M, Calanog A. Vulvar Paget's disease: the need to exclude an invasive lesion. Gynecol Oncol 1990;38:81-9.

7. Kanitakis J. Mammary and extramammary Paget's disease. J Eur Acad Dermatol Venereol 2007;21:581-90.

8. Lloyd J, Flanagan AM. Mammary and extramammary Paget's disease. J Clin Pathol 2000;53:742-9.

9. Curtin JP, Rubin SC, Jones WB, Hoskins WJ, Lewis JL Jr. Paget's disease of the vulva. Gynecol Oncol 1990;39:374-7.

10. Fishman DA, Chambers SK, Schwartz PE, Kohorn El, Chambers JT. Extramammary Paget's disease of the vulva. Gynecol Oncol 1995;56:266-70.

11. Kodama S, Kaneko T, Saito M, Yoshiya N, Honma S, Tanaka K. A clinicopathologic study of 30 patients with Paget's disease of the vulva. Gynecol Oncol 1995;56:63-70.

12. Parker LP, Parker JR, Bodurka-Bevers D, Deavers M, Bevers MW, Shen-Gunther J, et al. Paget's disease of the vulva: pathology, pattern of involvement, and prognosis. Gynecol Oncol 2000;77:183-9.

13. Roh HJ, Kim DY, Kim JH, Kim YM, Kim YT, Nam JH. Paget's disease of the vulva: evaluation of recurrence relative to symptom duration, volumetric excision of lesion, and surgical margin status. Acta Obstet Gynecol Scand 2010;89:962-5.

14. Geisler JP, Stowell MJ, Melton ME, Maloney CD, Geisler HE. Extramammary Paget's disease of the vulva recurring in a skin graft. Gynecol Oncol 1995;56:446-7.

15. Tjalma WA, Cooremans ID, Jeuris W, Van Marck EA, Monaghan $J M$. Recurrent Paget's disease of the vulva in a myocutaneous flap: case report and review of the literature. Eur I Gynaecol Oncol 2001;22:13-5. 


\section{피부이식 및 피판재건술을 이용한 외음부 파제트병 치료 3예}

전북대학교 의학전문대학원 ${ }^{1}$ 산부인과학교실, ${ }^{2}$ 성형외과학교실

조동휴, 노시균 ${ }^{2}$, 이정헌 ${ }^{1}$

유방외 파제트병은 서서히 진행하는 홍반성 습진양 피부 병변으로 주로 폐경 여성에서 발생하는 비교적 드문 상피내선암종이다. 외음부 파제트병은 전체 외음부 종양의 약 $1 \%$ 이하를 차지하며, 광범위 국소절제술이 가장 좋은 치료 방법으로 알려져 있다. 그러나 재발을 방지 하기 위해 충분한 절제연을 설정하여 광범위 절제술을 시행할 경우, 단순 봉합만으로 결손 부위를 재건하는 것은 매우 어려우므로 피부이 식과 피판술을 이용한 재건술이 상당히 유용할 수 있다. 저자들은 피하조직을 포함한 광범위 국소절제술 후 피부이식과 피판술을 이용한 회음부재건술을 시행하여 성공적으로 치료하였던 외음부 파제트병 3예를 경험하였기에 문헌 고찰과 함께 보고하는 바이다.

중심단어: 파제트병, 외음부, 피부이식과 피판술 